\title{
Kesehatan Jiwa yang Terabaikan dari Target Milenium
}

\section{Sri Idaiani}

\begin{abstract}
Abstrak
Millenium Development Goals (MDG) yang dicanangkan pada tahun 2000 sangat didominasi oleh penyakit menular serta kesehatan ibu dan anak, tetapi mengabaikan berbagai masalah penyakit tidak menular. Tidak sedikitpun terlintas dalam benak para pemimpin dunia itu target dan indikator yang menyentuh atau berhubungan dengan masalah kesehatan jiwa. Tulisan ini bertujuan membahas posisi kesehatan jiwa di seluruh dunia yang cenderung semakin memprihatinkan, tetapi justru terabaikan dari target MDG. Pencapaian target milenium tampaknya tidak memperhitungkan beban penyakit akibat berbagai masalah kejiwaan. Padahal, jika dibiarkan, pada masa mendatang masalah kesehatan jiwa akan menjadi besar seperti yang tengah dihadapi oleh berbagai negara maju. Berdasarkan prediksi tahun 2020, depresi unipolar akan menempati rangking ke-2 penyebab beban penyakit. Beberapa upaya dapat ditempuh untuk memelihara kelangsungan program kesehatan jiwa, antara lain tetap menjalankan kebijakan kesehatan jiwa dan upaya advokasi untuk mendapatkan anggaran yang memadai. Hal tersebut dapat dilakukan dengan memasukkan berbagai isu internasional dan lokal spesifik serta mempersiapkan landasan hukum yang merupakan salah satu persyaratan pengajuan pendanaan.
\end{abstract}

Kata kunci : Pencapaian target milenium, kesehatan jiwa, beban penyakit.

\section{Abstract}

Since the Millenium Development Goals was developed in 2000, many health priorities are directed to that goals. The MDGs dominated by communicable diseases, maternal and child health, meanwhile non-communicable diseases get less attention and was allocated relatively low budget to maintain their programs. The objective of this study was to discuss mental health position from MDGs perspectives. MDGs have ignored mental health by no target or indicator of MDGs is related to mental disorders. The MDGs did not calculate the non-communicable burden of those diseases. That condition affected not only Indonesia as developing country but also in developed country, which cause low mental health budget from the total health budget country. It will become serious problem in the future as it was predicted that that uni-polar depression will rank second as the leading burden of disease. The mental health policy and advocacy have to implement to maintain the program by proposing sufficient budget and developing international and local specific issues while preparing the legal foundation as a requirement to propose the budget.

Key words : MDGs, mental health, burden of diseases. 
Indonesia merupakan bagian negara serumpun di kawasan Asia Tenggara yang terletak di antara Samudra Hindia dan Samudra Pasifik yang penting dan bergolak secara dinamis. Negara yang terdiri dari 17.508 pulau ini terhampar luas di daerah strategis sekitar khatulistiwa yang beriklim tropis yang relatif lebih bersahabat, Indonesia adalah negara berkembang dengan jumlah penduduk (240.271.522 jiwa), terbesar yang relatif kurang produktif. Itulah sebabnya negeri ini dihadapkan pada berbagai masalah besar yang memerlukan kearifan, komitmen politis, perhatian serius, kerja keras dan dana besar untuk meningkatkan derajat kesehatan masyarakat. Upaya keras tersebut antara lain meliputi pengentasan kemiskinan, peningkatan pendidikan, pemberantasan terorisme, konsolidasi demokrasi, reformasi ekonomi dan keuangan, pemberantasan korupsi, perubahan iklim, dan pengendalian berbagai wabah penyakit.

Indonesia menyandang komposisi penduduk yang secara sangat jelas memperlihatkan porsi terbesar kelompok usia produktif yang menuntut penyediaan lapangan kerja yang besar. Beberapa indikator pembangunan kesehatan Indonesia telah memperlihatkan perbaikan, tetapi perbaikan tersebut berjalan relatif sangat lambat jika dibandingkan dengan perbaikan rerata kesehatan masyarakat yang terjadi di berbagai negara tetangga Asean. Hal tersebut dapat dilihat pada berbagai indikator populasi antara lain meliputi umur harapan hidup waktu lahir, angka kematian bayi, angka kematian ibu, angka kematian kasar, angka kematian spesifik berbagai penyakit yang dilaporkan.

Perlu disadari bahwa peningkatan umur harapan hidup rata-rata waktu lahir tidak mencerminkan perbaikan kualitas penduduk. Karena hal tersebut merupakan kontribusi utama dari penurunan angka kematian bayi yang terjadi pada awal masa transisi demografi, ketika berbagai program kesehatan untuk ibu dan anak mendapatkan prioritasnya yang tinggi. Dengan demikian, meskipun tanpa upaya intervensi pada kelompok usia dewasa yang mampu meningkatkan kualitas hidup, usia harapan hidup waktu lahir masih tetap dapat ditingkatkan. Bagaimanapun, hal tersebut tidak dapat secara langsung digunakan untuk mencerminkan peningkatan kualitas hidup dan kesehatan masyarakat. Berdasarkan proyeksi penduduk per provinsi yang dikeluarkan oleh Badan Pusat Statistik Indonesia (BPS) pada tahun 2003, terlihat bahwa umur harapan hidup cenderung meningkat dari tahun ke tahun meskipun peningkatan tersebut bervariasi secara sangat besar antar seluruh wilayah provinsi di Indonesia. Umur harapan hidup waktu lahir penduduk Indonesia pada tahun 2003, adalah 66,18 tahun, dengan angka tertinggi berada di Daerah Khusus Yogjakarta (72,17 tahun), diikuti Daerah Khusus Ibukota Jakarta (72,12 tahun) dan yang terendah dilaporkan di Nusa Tenggara Barat (63,51 tahun) (Lihat Gambar 1).

Indikator keberhasilan pembangunan kesehatan yang lain adalah penurunan angka kematian bayi. Pada tahun 1999, angka kematian bayi di Indonesia adalah 46 per 1000 kelahiran dan pada tahun 2003 terjadi penurunan menjadi 43 per 1000 kelahiran. Berdasarkan profil kesehatan tahun 2008, angka kelahiran bayi di Indonesia tersebut termasuk dalam kategori sedang (35 per 1000 kelahiran). Selanjutnya, angka kematian ibu digunakan untuk melakukan penilaian terhadap kewaspadaan perilaku hidup sehat, status gizi masyarakat, kesehatan ibu, akses dan fasilitas pelayanan kesehatan. Pada tahun 1998-2003, angka kematian ibu (307 per 100.000 kelahiran hidup) masih tergolong tinggi jika dibandingkan dengan berbagai negara tetangga di ASIA. Selanjutnya, estimasi angka kelahiran kasar (crude birth rate) 18.84 kelahiran per 1.000 penduduk, estimasi angka kematian kasar 6.24 kematian per 1.000 penduduk.1,2 Dengan kondisi Indonesia yang seperti itu, prioritas pembangunan kesehatan di Indonesia tampaknya masih lebih ditujukan kepada masalah kematian ibu, kematian bayi serta

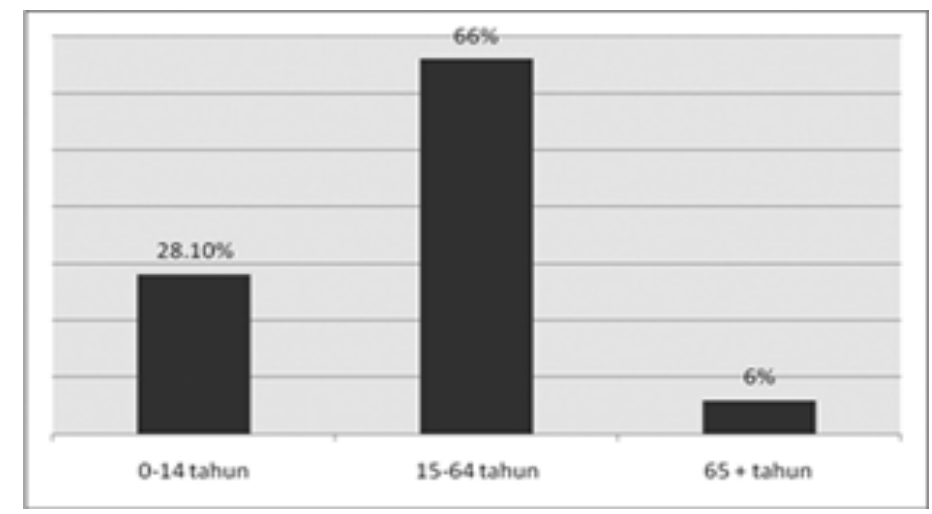

Gambar 1. Komposisi Jumlah Penduduk Indonesia berdasarkan Kelompok Umur 
penyakit menular dan kekurangan gizi yang umumnya dialami oleh berbagai negara berkembang. 1,2 Padahal, berbagai penyakit tidak menular telah memperlihatkan tren yang meningkat pesat yang memerlukan perhatian serius dan upaya yang sungguh-sungguh.

Berbagai penyakit yang paling banyak menempati ruang perawatan rumah sakit umum di seluruh wilayah di Indonesia antara lain adalah penyakit diare dan gastroenteritis $(8,5 \%)$, penyakit demam tifoid dan paratifoid, demam berdarah dengue, perdarahan intrakranial, gangguan masa kehamialan dan aborsi, tuberculosis paru, gagal ginjal, diabetes melitus, pneumonia, gastritis dan duodenitis $(1,6 \%) .{ }^{1}$ Hal tersebut tampaknya sejalan dengan pencapaian target Milenium atau lebih popular dengan istilah Millennium Development Goals (MDGs). Target Milenium pada dasarnya adalah serangkaian target yang disepakati bersama antara berbagai negara maju dan negara sedang berkembang di dunia dan ditanda tangani oleh 147 kepala negara pada bulan September 2000. Tulisan ini bertujuan untuk membahas kedudukan kesehatan jiwa ditengah-tengah hiruk pikuk suasana upaya Pencapaian Terget Milenium tersebut. Kesehatan jiwa merupakan suatu masalah besar dan penting yang berkontribusi besar terhadap derajat kesehatan umat manusia, tetapi tersisih dari prioritas MDGs. Hal tersebut terjadi karena penyakit jiwa tidak dianggap sebagai prioritas di berbagai negara berkembang di seluruh dunia. Padahal, di negara maju masalah kesehatan jiwa tersebut terbukti berkontribusi pada besar beban penyakit, sehingga selalu mendapat prioritas untuk dicegah dan dikendalikan.

\section{Target Milenium dan Beban Penyakit}

Pencapaian Target Milenium dicanangkan secara luas pada saat Deklarasi Millenium pada tahun 2000. ${ }^{3}$ Deklarasi tersebut ditetapkan untuk menciptakan suasana pembangunan yang kondusif secara nasional dan internasional serta untuk mengeliminasi kemiskinan. Deklarasi ini menghimpun delapan tujuan yang terdiri dari 18 target pencapaian dengan tingkat keberhasilan yang diukur melalui 48 indikator pencapaian. Kedelapan tujuan tersebut meliputi eradikasi kemiskinan dan kelaparan, pendidikan dasar untuk semua, promosi kesetaraan gender dan pemberdayaan wanita, penurunan angka kematian ibu, peningkatan kesehatan ibu, memerangi HIV/AIDS, malaria dan penyakit lain, memelihara kelestarian lingkungan, mengembangkan kemitraan global untuk pembangunan. ${ }^{3}$ Dari semua tujuan tersebut, target dan indikator yang ditetapkan menampilkan bahwa peran utama ditempati oleh sektor kesehatan dan sektor pendidikan. Bidang kesehatan lebih menekankan upaya pengendalian penyakit menular yang umumnya menjadi penyebab utama kematian di negara berkembang. ${ }^{3}$ Dengan landasan Pencapaian Target Milenium tersebut, kesehatan jiwa tampaknya termarginalisasikan dan tidak menjadi prioritas, kemungkinan karena gangguan kesehatan jiwa dianggap sebagai penyakit yang tidak serius sehingga dianggap tidak berhubungan langsung dengan kematian.

Kondisi atau penyakit yang secara jelas tercantum di dalam Target Milenium ternyata adalah infeksi saluran pernafasan bawah, HIV/AIDS, diare, malaria dan tuberculosis. Ini merupakan kelompok penyakit yang secara klasik dipahami merupakan masalah kesehatan utama di negara berkembang. Penempatan prioritas tersebut tentu sangat rasional sehingga dapat dipahami. Namun, kondisi kejiwaan (depresi unipolar) juga termasuk sebagai salah satu dari sepuluh penyebab beban penyakit dan cedera di negara berkembang (Lihat Tabel 1). Berbagai kondisi yang berhubungan dengan kesehatan jiwa meliputi kecemasan, depresi, ketergantungan alkohol, penyalahgunaan bahan berbahaya serta skizofrenia merupakan masalah kesehatan penting yang beranjak dengan cepat mendera para penduduk miskin yang tidak berdaya. Berbagai masalah kesehatan yang diutarakan di atas memberikan sumbangan yang besar terhadap proporsi disability adjusted life years (DALYs) dan years lived with disability (YLDs). ${ }^{4-7}$

Sebaliknya, berbagai penyakit tidak menular seperti kardiovaskuler, diabetes mellitus penyakit paru-paru obstruktif, penyakit otot dan sendi dan penyakit kejiwaan, meskipun secara jelas berkontribusi terhadap penyebab kematian ternyata tidak menjadi prioritas dalam

Tabel 1. Sepuluh Penyebab Beban Penyakit dan Cedera, 2002

\begin{tabular}{lc}
\hline Penyakit & $\%$ of total DALYs \\
\hline Kondisi perinatal & $6.5 \%$ \\
Infeksi saluran pernafasan bawah & $5.8 \%$ \\
HIV/AIDS & $5.8 \%$ \\
Depresi Unipolar & $4.5 \%$ \\
Penyakit Diare & $4.1 \%$ \\
Penyakit Jantung Iskemik & $3.9 \%$ \\
Penyakit cerebrovaskular & $3.3 \%$ \\
Malaria & $3.0 \%$ \\
Kecelakaan lalu lintas & $2.6 \%$ \\
Tuberculosis & $2.4 \%$ \\
\hline
\end{tabular}

Tabel 2. Penyebab Utama Beban Penyakit di Negara Maju, 2002

\begin{tabular}{lc}
\hline Penyakit & $\%$ of total DALYs \\
\hline Penyakit jantung iskemik & $9.1 \%$ \\
Depresi unipolar & $7.3 \%$ \\
Penyakir cerebrovaskuler & $6.4 \%$ \\
Penggunaan alkohol & $3.6 \%$ \\
Kehilangan pendengaran onset dewasa & $2.8 \%$ \\
Penyakit paru obstruktif & $2.6 \%$ \\
Kecelakaan lalu lintas & $2.5 \%$ \\
Penyakit trachea, bronchus, paru, kanker & $2.4 \%$ \\
Alzheimer and demensia lain & $2.3 \%$ \\
Mencederai diri sendiri & $2.3 \%$ \\
\end{tabular}


Tabel 3. Penyebab Utama Beban Penyakit di Negara Berkembang Tahun 2002

\begin{tabular}{llll}
\hline \multicolumn{2}{c}{ Angka Kematian Rendah } & \multicolumn{2}{c}{ Angka Kematian Tinggi } \\
\hline & $\%$ of total DALYs & & $\%$ of total DALYs \\
\hline Depresi unipolar & $6.0 \%$ & HIV/AIDS & $9.2 \%$ \\
Kondisi perinatal & $5.9 \%$ & Infeksi saluran pnafas bawah & $8.5 \%$ \\
Cerebrovasculer & $5.0 \%$ & Kondisi perinatal & $8.0 \%$ \\
Kecelakaan lalu lintas & $3.7 \%$ & Diare & $5.8 \%$ \\
Jantung iskemik & $3.3 \%$ & Malaria & $5.1 \%$ \\
Paru obstruktif & $3.1 \%$ & Kondisi ibu & $3.1 \%$ \\
Infeksi saluran nafas Bawah & $26 \%$ & Depresi unipolar & $3.1 \%$ \\
Tuberkulosis & $2.4 \%$ & Jantung Iskemik & $2.9 \%$ \\
Diare & $2.4 \%$ & Campak & $2.8 \%$ \\
Katarak & $2.4 \%$ & Tuberculosis & $2.7 \%$ \\
\end{tabular}

Tabel 4. Prediksi Penyebab Utama Beban Berdasarkan Rangking Tahun 2002

\begin{tabular}{clc}
\hline Rangking & Seluruh Negara & $\%$ of total DALYs \\
\hline 1 & Penyakit jantung iskemik & $5.9 \%$ \\
2 & Depresi unipolar & $5.7 \%$ \\
3 & Kecelakaan lalu lintas & $5.1 \%$ \\
4 & Penyakit cerebrovaskular & $4.4 \%$ \\
5 & Penyakit paru obstruktif & $4.2 \%$ \\
6 & Infeksi saluran pernafasan bawah & $3.1 \%$ \\
7 & Tuberculosis & $3.0 \%$ \\
8 & Cedera peperangan & $3.0 \%$ \\
9 & Diare & $2.7 \%$ \\
10 & HIV/AIDS & $2.6 \%$ \\
\hline
\end{tabular}

Pencapaian Target Milenium. ${ }^{3}$ Mengabaikan berbagai penyakit tidak menular termasuk penyakit kejiwaan tersebut berarti bahwa kita kehilangan peluang untuk mendapatkan kontribusi dari berbagai penyakit yang sesungguhnya penting tersebut. Itu berarti pendanaan untuk program berbagai penyakit tidak menular tersebut tidak tersedia secara memadai sehingga tidak mungkin dapat dilakukan pengendalian secara efektif. Padahal, karakteristik penyakit tidak menular tersebut umumnya menampilkan kelainan yang permanen sehingga bersifat kronis dan tergantung pada fasilitas kesehatan yang cenderung mahal dan tidak terkendali. Berbagai upaya pencegahan berupa modifikasi lingkungan dan perubahan perilaku bersifat lebih kompleks dan memerlukan upaya yang lebih besar. Upaya pencegahan dan pengendalian penyakit tidak menular dan kejiwaan rasanya mustahil dapat ditangani secara mandiri oleh masyarakat. Oleh sebab itu, keterlibatan yang lebih serius oleh pemerintah dan badan penyandang dana internasional masih sangat diperlukan (Lihat Tabel 2).

Di negara maju, secara umum, penyakit yang menjadi masalah kesehatan justru adalah penyakit tidak menular. Apabila beban penyakit di negara berkembang dikelompokkan berdasarkan angka kematian tinggi dan angka kematian rendah, hasilnya terlihat seperti di Tabel
3. Hal tersebut dapat dipahami karena negara yang lebih maju telah mampu mengendalikan masalah kependudukan dan penyakit infeksi. ${ }^{4}$ Bagaimanapun, kondisi dinegara maju tersebut dapat terjadi di berbagai negara berkembang, mengingat determinan utama penyakit tidak menular dan kejiwaan adalah urbanisasi dan industrialisasi. Upaya promosi dan pencegahan penyakit tidak menular seharusnya dilakukan sejak dini pada kelompok usia bayi dan anak anak, sebelum kelainan biologis yang terjadi berkembang permanen. Berdasarkan Laporan Badan Kesehatan Dunia (WHO), gangguan jiwa merupakan salah satu kondisi yang menyumbangkan beban penyakit yang besar melalui kesakitan, kecacatan dan kematian dini terutama di negara yang sedang berkembang.

Di negara berkembang yang dengan angka kematian rendah dan tinggi, berbagai penyakit infeksi berperan besar sebagai penyumbang beban akibat penyakit. Penyakit tidak menular seperti penyakit cerebro vaskuler dan jantung iskemik, paru obstruktif, katarak juga mulai memberikan kontribusi terhadap beban penyakit (Lihat Tabel 4). Hal ini terjadi akibat penuaan populasi di negara berkembang memberi peluang untuk penyakit-penyakit tidak menular untuk bermanifestasi secara klinis. Kini, berbagai negara berkembang termasuk Indonesia telah memperlihatkan beban ganda masalah kesehatan masyarakat. Meskipun penyakit menular memperlihatkan kecenderungan yang menurun, tetapi masih tergolong tinggi, sementara berbagai penyakit tidak menular telah memperlihatkan peningkatan yang nyata.

\section{Kesehatan Jiwa}

Kedudukan kesehatan jiwa di dalam Pencapaian Target Milenium dapat ditinjau dari aspek pengurangan kemiskinan, kematian bayi, anak dan kesehatan ibu. Kemiskinan adalah salah satu determinan status kesehatan yang berkontribusi besar terhadap kesehatan dan produktifitas manusia. Orang yang sakit telah kehilangan fungsi produktifnya dan mangkir bekerja, untuk memu- 
lihkan fungsi produktif setelah sakit diperlukan waktu yang lama dan biaya besar. Pemulihan penduduk miskin yang sakit yang diserahkan pada keluarga, sehingga cenderung kembali sakit. Lingkungan dengan kemiskinan merupakan kondisi yang rentan terhadap pendidikan yang rendah, kekerasan dalam rumah tangga, semua perilaku agresif berisiko untuk mengembangkan kondisi stres menjadi gangguan jiwa. Kemiskinan telah diketahui secara luas merupakan faktor risiko depresi dan cemas, sehingga upaya mengentaskan kemiskinan berpengaruh positif terhadap derajat kesehatan jiwa. ${ }^{3}$ Meskipun demikian, upaya pengentasan kemiskinan memerlukan biaya besar dan waktu yang panjang, sehingga kontribusinya terhadap kenaikan kesehatan jiwa masyarakat tidak serta-merta dapat dirasakan.

Saat ini, angka kematian bayi dan anak yang tinggi masih menjadi prioritas pembangunan di negara berbagai berkembang. Di Asia bagian Selatan telah terdapat bukti penelitian yang menyatakan bahwa kematian pada anak banyak berhubungan dengan kondisi kejiwaan ibu. Ibu yang mengalami gangguan kesehatan jiwa cenderung menelantarkan anak yang berujung pada kejadian gizi buruk. Suatu penelitian di Pakistan menemukan bahwa ibu yang mengalami depresi pada masa kehamilan dan masa postnatal berisiko tiga kali lebih besar untuk mempunyai bayi dengan berat badan rendah serta pendek pada usia di bawah satu tahun daripada ibu yang tidak mengalami depresi. Di samping itu, ibu yang mengalami depresi umumnya mempunyai masalah dengan pemberian air susu ibu, sehingga berakibat bayi tidak mendapatkan ASI yang cukup dan berisiko mengalami diare. Diare kronik akan menimbulkan kondisi kekurangan gizi dan memicu kematian bayi. ${ }^{3}$ Di negara berkembang telah banyak penelitian yang menyebutkan bahwa sekitar $10-30 \%$ ibu mengalami depresi yang disebabkan berbagai faktor seperti kelelahan, tidur yang tidak cukup. Tanpa penanganan secara baik terhadap berbagai kondisi tersebut akan berdampak pada peningkatan kejadian bunuh diri.3,8-11 Dengan demikian, dapat dipahami bahwa berbagai upaya yang dilakukan untuk mencegah dan mengendalikan berbagai masalah kejiwaan dapat berkontribusi positif terhadap kematian bayi dan kematian ibu.

\section{Penguatan Sistem Kesehatan Nasional}

Dana untuk mencapai Target Milenium tersebut disponsori oleh berbagai negara maju, sementara negara berkembang lebih banyak berperan sebagai penerima donor. ${ }^{3}$ Negara maju menyikapi masalah kesehatan global dengan lebih berpihak pada penyakit menular serta kematian bayi, anak dan peningkatan kesehatan ibu. Padahal, masalah kesehatan utama di negara-negara maju adalah berbagai penyakit tidak menular. Hal tersebut tentu harus diterima sebagai suatu kesepakatan ber- sama dunia internasional, tanpa mengabaikan berbagai penyesuaian terhadap berbagai aspek lokal spesifik yang dihadapi oleh setiap wilayah ataupun negara. Misalnya, beberapa negara di Amerika Latin telah dinyatakan berhasil mencencapai Target Milenium. Mereka masih menghadapi berbagai masalah lokal yang harus dipecahkan secara regional. Dalam kondisi seperti itu, penyakit tidak menular mulai tampil memperlihatkan peningkatan kebutuhan pencegahan dan pengendalian untuk mendapat perhatian pemerintah.3,12

Sistem Kesehatan Nasional disusun untuk melindungi segenap lapisan masyarakat dimanapun mereka bermukim dari berbagai masalah yang mengancam kehidupan termasuk terhadap berbagai determinan yang mempengaruhi penyakit jiwa. Di Indonesia, seluruh upaya kesehatan yang ditujukan untuk melindungi seluruh lapisan masyarakat tersebut tercantum pada sistem kesehatan nasional yang mengacu pada UUD 1945, UU Kesehatan, UU Rencana Pembangunan Jangka Panjang Nasional serta Wawasan Nusantara. Sistem Ketahanan Nasional menjadi landasan umum pelaksanaan kesehatan di Indonesia yang secara lebih spesifik diuraikan pada berbagai kebijakan yang ditetapkan oleh jajaran di bawah menteri yang setara dengan eselon satu (I)..$^{13}$

Suatu kebijakan akan berkembang menjadi efektif apabila mempunyai komponen yang tertuang dalam aspek legal yang antara lain meliputi Undang-Undang, Peraturan Pemerintah, Peraturan Menteri hingga Peraturan Daerah yang memberikan kemungkanan untuk diimplementasikan. Di samping perangkat hukum tersebut, suatu kebijakan baru dapat diimplementasikan apabila mendapat dukungan pembiayaan yang memadai serta pemantauan dan evaluasi terhadap pelaksanaan. Suatu dokumen tertulis tentang kebijakan dinyatakan ada jika telah diimplementasikan, betapapun baiknya suatu kebijakan jika tidak dilaksanakan maka kebijakan tersebut dapat dinyatakan tidak ada. Saat ini, kebijakan bidang kesehatan jiwa di Indonesia tidak didukung oleh dana yang memadai atau bahkan tidak mendapat alokasi dana sama sekali, sehingga dapat dipahami jika beberapa kalangan menganggap bahwa kebijakan tersebut belum ada.

Kebijakan kesehatan jiwa disusun dengan mengacu pada sistem kesehatan nasional dengan memperhatikan situasi nasional dan global. Sebagai contoh, kebijakan kesehatan jiwa telah mencantumkan aspek pelayanan primer, sekunder serta tersier. ${ }^{14-16}$ Dengan demikian, ada pembagian tugas yang jelas di berbagai tingkat pelayanan kesehatan. Di tingkat pelayanan primer pada puskesmas dan kesehatan jiwa masyarakat diberikan pelayanan dasar yang dilakukan oleh dokter umum. Pelayanan tingkat sekunder lebih ditujukan pada penguatan rumah sakit umum dalam pelayanan kesehatan jiwa untuk mendukung dan memperkuat pelayanan 
Tabel 5. Hubungan Anggaran Kes Jiwa dan Proporsi Total Anggaran Kesehatan dengan Kebijakan dan Indikator Program (n =89)

\begin{tabular}{|c|c|c|c|c|c|}
\hline \multirow{2}{*}{ Kebijakan/Program } & \multirow{2}{*}{ Katagori } & \multicolumn{4}{|c|}{ Proporsi Total Anggaran Kesehatan } \\
\hline & & $0-1 \%$ & $>1-5 \%$ & $>5 \%$ & $X^{2}(d f=2)$ \\
\hline \multirow[t]{2}{*}{ Kesehatan Jiwa } & Ada & 22 & 19 & 18 & 1.502 \\
\hline & Tidak Ada & 11 & 13 & 06 & \\
\hline \multirow{2}{*}{ Penyalahgunaan Zat } & Ada & 21 & 20 & 20 & 3.345 \\
\hline & Tidak Ada & 12 & 12 & 04 & \\
\hline \multirow[t]{2}{*}{ Kesehatan Jiwa Nasional } & Ada & 28 & 25 & 17 & 1.634 \\
\hline & Tidak Ada & 05 & 07 & 07 & \\
\hline \multirow{2}{*}{ Legislasi Kesehatan Jiwa } & Ada & 21 & 24 & 21 & 4.147 \\
\hline & Tidak Ada & 12 & 08 & 03 & \\
\hline \multirow{2}{*}{ Disabilitas } & Ada & 22 & 22 & 23 & $7.497 *$ \\
\hline & Tidak Ada & 11 & 10 & 01 & III > I, II \# \\
\hline \multirow[t]{2}{*}{ Terapi Obat } & Ada & 29 & 28 & 21 & - \\
\hline & Tidak Ada & 04 & 04 & 03 & \\
\hline \multirow[t]{2}{*}{ Kes Jiwa di Pelayanan Primer } & Ada & 30 & 29 & 23 & - \\
\hline & Tidak Ada & 03 & 03 & 01 & \\
\hline \multirow[t]{2}{*}{ Pelatihan Kes Jiwa di Pelayanan Primer } & Ada & 24 & 19 & 17 & 1.493 \\
\hline & Tidak Ada & 09 & 13 & 07 & \\
\hline \multirow[t]{2}{*}{ Dukungan Kes Jiwa Masyarakat } & Ada & 23 & 22 & 19 & 0.864 \\
\hline & Tidak Ada & 10 & 10 & 05 & \\
\hline \multirow{2}{*}{ Psikotropika 3 Klasifikasi } & Ada & 25 & 27 & 22 & 2.563 \\
\hline & Tidak Ada & 08 & 05 & 02 & \\
\hline
\end{tabular}

puskesmas. Pelayanan tersier lebih diarahkan kepada upaya kesehatan rujukan spesialistik serta pendidikan sumber daya kesehatan dibidang kesehatan jiwa.

Isu global seperti deinstitusionalisasi, kesehatan jiwa masyarakat, pengobatan yang efektif dan modern juga telah diserap dalam kebijakan kesehatan jiwa yang ada. ${ }^{14,15}$ Namun, berbagai kebijakan tersebut tidak didukung oleh sistem pendanaan yang memadai yang menjadi indikator penting dari pelaksanaan suatu kebijakan. Beberapa program kesehatan jiwa mendapat alokasi pendanaan dengan cara mendekatkan masalah dengan kebijakan lain yang mempunyai landasan yang lebih popular. Sebagai contoh, masalah konseling bagi orang dengan HIV/AIDS (ODHA) yang layak dilakukan pemantauan oleh kesehatan jiwa lebih banyak mendapat pendanaan dari pembiayaan program penyakit HIV/AIDS. Berbagai program kesehatan jiwa juga sering mendapatkan pembiayaan dari bidang lain seperti promosi, pelayanan kesehatan serta kesehatan masyarakat yang lain. Berbagai kondisi yang memprihatinkan tersebut pada dasarnya terjadi sebagai akibat kelemahan landasan hukum yang menjadi prasarat bagi alokasi pembiayaan program kesehatan.

Pada masa lalu, Indonesia pernah memiliki UU Kesehatan Jiwa yaitu UU No. 3 tahun 1966 yang memberikan dukungan kuat bagi penyelenggaraan kesehatan jiwa. Undang-undang tersebut telah memberikan peluang besar bagi kesehatan jiwa untuk menampilkan kinerja kesehatan jiwa yang membesarkan hati. Namun, pada tahun 1992, UU No. 23 tentang Kesehatan yang menyebabkan UU No. 3 Tahun 1966 tentang Kesehatan Jiwa menjadi tidak berlaku lagi. Empat pasal di dalam UU No. 23 yang mengatur kesehatan jiwa karena ketiadaan dukungan operasional pelaksanaan berupa peraturan pemerintah. Sebagaimana diketahui bahwa untuk dapat diimplentasikan dan dijadikan landasan hukum, berbagai pasal harus dijabarkan melalui Peraturan Pemerintah. Pasal 27 UU Kesehatan mewajibkan ketentuan tentang kesehatan jiwa dan upaya penanggulangan ditetapkan dengan Peraturan Pemerintah. Di sinilah letak permasalahan yang rumit, karena sampai 15 tahun sejak diterbitkan UU No. 23 Tahun 1992 tersebut, Perpu tentang kesehatan jiwa tersebut tak kunjung tersusun sehingga berakibat pada kesulitan dalam penyusunan rencana kegiatan dan alokasi anggaran sektor kesehatan jiwa. Maka, jadilah program kesehatan jiwa seperti yang terlihat sekarang ini, hanya sebagai pelengkap tanpa dukungan politis dan keinginan yang kuat untuk melaksanakanya.

Indonesia termasuk salah satu negara yang mempunyai anggaran kesehatan jiwa yang sangat kecil di bawah $1 \%$ dari total anggaran kesehatan yang ada. Kondisi anggaran kesehatan jiwa seperti itu ditemukan di berbagai negara di Asia Tenggara dan Afrika. Berbagai negara berpenghasilan rendah cenderung menyediakan alokasi anggaran kesehatan jiwa yang jauh lebih rendah daripada negara-negara yang berpenghasilan tinggi. ${ }^{17}$ Beberapa negara dengan anggaran kesehatan jiwa $\leq 1 \%$, $>1-5 \%$ dan $>5 \%$ masih belum mempunyai kebijakan ke- 
sehatan jiwa yang tampaknya tidak berhubungan dengan total anggaran yang dialokasikan untuk program kesehatan jiwa, kecuali kebijakan yang terkait disabilitas. ${ }^{16}$ Dengan membandingkan negara-negara yang berpenghasilan menengah sampai rendah hingga negara maju yang berpenghasilan tinggi, umumnya kesehatan jiwa tidak mendapatkan anggaran yang besar. Hal tersebut mengindikasikan prioritas yang diberikan oleh negara terhadap kesehatan jiwa terbukti sangat rendah. ${ }^{17}$ Berbagai fakta tentang beban penyakit yang tinggi, tidak memberikan pengaruh yang berarti pada pandangan dunia yang lebih rendah terhadap kesehatan jiwa dibandingkan dengan masalah kesehatan yang lain. Data tentang hubungan kesehatan jiwa dengan kebijakan serta anggaran kesehatan jiwa di seluruh dunia disajikan pada Tabel 5.

Apabila kondisi seperti prediksi beban penyakit pada tahun 2020 terus berlanjut, pada gilirannya nanti depresi unipolar akan berkembang menjadi penyebab kedua beban penyakit. Pergeseran berbagai penyakit tersebut sebaiknya disikapi secara lebih arif dengan mempersiapkan pembangunan kesehatan yang memberi prioritas kepada penyakit tidak menular khususnya gangguan jiwa. Prioritas kesehatan jiwa yang rendah dapat disikapi dengan berbagai cara. Beberapa negara di Asia Selatan dan Amerika Latin melakukan berbagai penelitian yang menunjukkan hubungan kesehatan jiwa dengan beberapa indikator Pencapaian Target Milenium. Upaya yang menunjukkan beban penyakit menular dan tidak menular yang besar lebih banyak disponsori oleh lembaga internasional seperti Bank Dunia dan WHO. Hal tersebut disebabkan oleh perhitungan beban penyakit memerlukan data dan informasi yang besar dan dilakukan dengan metode yang sama seperti untuk mendapatkan gambaran yang dapat dibandingkan.

\section{Kesimpulan}

Pada masa yang akan datang, masalah kesehatan jiwa tampaknya akan menjadi penyebab beban penyakit yang besar seperti yang tengah dihadapi oleh berbagai negara maju di seluruh dunia saat ini. Berdasarkan prediksi tahun 2020, depresi unipolar akan menempati rangking ke-2 penyebab beban penyakit. Namun, masalah kesehatan tersebut terlepas dari dukungan undang-undang sehingga tidak mendapat tempat yang layak sebagai masalah kesehatan masyarakat prioritas. Kondisi ini mencemaskan, karena masalah kesehatan jiwa yang dihadapi semakin luas dan komplek serta mengancam kesehatan dan keselamatan penduduk. Mengabaikan masalah kesehatan jiwa akan menggiring kita pada persoalan besar yang akan mengusung penyesalan yang berkepanjangan. Negeri ini bukan warisan dari generasi tua pada masa lalu, tetapi adalah amanah yang dititipkan generasi muda yang akan menagihnya pada masa yang akan datang.
Dampak buruk yang diuraikan di atas mungkin tidak dialami oleh generasi yang sekarang mempunyai kewenangan, tetapi oleh generasi masa mendatang yang sekarang belum mempunyai kewenangan apa-apa.

\section{Saran}

Beberapa upaya dapat ditempuh untuk memelihara kelangsungan program kesehatan jiwa, antara lain tetap menjalankan kebijakan kesehatan jiwa dan upaya advokasi untuk mendapatkan anggaran yang memadai. Hal tersebut dapat dilakukan dengan memasukkan berbagai isu internasional dan lokal spesifik serta mempersiapkan landasan hukum yang merupakan salah satu persyaratan pengajuan pendanaan. Indonesia perlu melakukan penelitian yang berhubungan dengan Pencapaian Target Milenium dari aspek kesehatan jiwa seperti yang dilakukan di banyak negara. Advokasi tentang besaran beban penyakit juga harus terus ditingkatkan agar tidak semua indikator kesehatan berbasis angka kematian. Selanjutnya, dapat dilakukan kajian pembiayaan kesehatan yang berhubungan dengan berbagai penyakit tidak menular khususnya di bidang kesehatan jiwa. Berbagai isu internasional serta lokal spesifik perlu dimasukkan dalam penyusunan kebijakan kesehatan di samping mengupayakan perangkat hukum sebagai landasan penyusunan kebijakan. Pencapaian Target Milenium adalah suatu kesepakatan bersama yang perlu disikapi dengan bijaksana. Selayaknya pemerintah tidak terpaku hanya pada target dan indikator yang tertulis jelas pada kesepakatan tersebut dan mengabaikan indikator lain yang telah diprediksi akan menjadi masalah kesehatan di masa yang akan datang.

\section{Daftar Kepustakaan}

1. The World Factbook [the homepage on the Internet]. [updated 2009 June 06; cited 2009 August 20]. Available from: https://www.cia.gov/library/publications/the-world-factbook/print/id.html.

2. Departemen Kesehatan Republik Indonesia. Profil kesehatan. Jakarta: Departemen Kesehatan RI; 2007

3. Miranda JJ, Patel V. Achieving the millennium development goals: does mental health play a role? [article on the internet]. PLoS Medicine. 2005 October [cited 2009 June]. 2005; Volume 2 (Issue 10): e291. Available from: www.plosmedicine.org

4. Ustun BT. The global burden of mental disorders. Am J Public Health.1999; 89(9):1315-18.

5. Mathers CD, Bernard C, Imburg KM, Inove M, Doris MF, Shibuya K, et al. Global burden of desease in 2002 : data source, method and result in global programme on evidence for health policy discussion paper No.54. World Health Organization; 2003.

6. Catherine M, Michaud CM, Murray CJL, Bloom. Burden of disease-implications for future research. Jama. 2001; 285(5): 535-39.

7. World Health Organization. Global burden of disease in 2002: data sources, methods and results. 2003

8. Chandran M, Tharyan P, Muliyil J, Abraham S. Post-partum depression 
in a cohort of women from a rural area of Tamil Nadu, India. Incidence and risk factors. Br J Psychiatry. 2002; 181: 499-504.

9. Cooper PJ, Tomlinson M, Swartz L, Woolgar M, Murray L, et al. Postpartum depression and the mother-infant relationship in a South African peri-urban settlement. Br J Psychiatry. 1999; 175: 554-8.

10. Fisher JR, Morrow MM, Ngoc NT, Anh LT. Prevalence, nature, severity and correlates of postpartum depressive symptoms in Vietnam. BJOG. 2004; 111: 1353-60.

11. Oates M. Suicide: The leading cause of maternal death. Br J Psychiatry. 2003; 183: 279-81.

12. Ollila E. Global health priorities: priorities of the wealthy? Global Health. 2005; 1: 6.

13. Departemen Kesehatan Republik Indonesia. Sistem kesehatan nasional,
Jakarta: Departemen Kesehatan RI; 2009.

14. Departemen Kesehatan Republik Indonesia. Rencana strategis pembangunan kesehatan jiwa 2001-2004. Jakarta: Departemen Kesehatan RI; 2003.

15. Departemen Kesehatan Republik Indonesia. Kebijakan nasional pembangunan kesehatan jiwa 2001-2005.Jakarta: Departemen Kesehatan RI; 2001.

16. Departemen Kesehatan Republik Indonesia. Kebijakan nasional kesehatan jiwa. Jakarta: Departemen Kesehatan RI; 2008.

17. Saxena S, Saraceno B. Budget and financing of mental health services: baseline information on 89 countries form WHO's project atlas. J Ment Health Policy Econ. 2003; 6: 135-43. 